\title{
CONDITION OF DEVELOPMENT AND PROBLEMS OF MODERN EDUCATION FOR ADULTS
}

\section{Maslianikova I. V.}

\section{INTRODUCTION}

Population aging is a world process. The proportion of older persons in the population is growing rapidly in developed countries and many developing countries. Ukraine is and will remain for the next few years one of the "oldest" countries in the world. It is projected that in 2051 the share of persons older than 60 years will be about 33\%. Naturally, this situation predetermines the need to allocate resources to support the older generation.

Adult education is a phenomenon characteristic of highly developed countries. Its feasibility is a generally accepted fact. The progressive ideas of this world sociocultural phenomenon are reflected in the documents of international organizations. Thus, the Hamburg Declaration of the UNESCO world conference (1997) States that "adult education is the key to the twenty-first century". The problem of adult development is defined as a priority problem in the international educational environment. Its special value was noted during the meetings of the "Big eight" (the Charter of Cologne, Cologne, 1999; "Education in a changing world" (Final document of the meeting of education Ministers of the "Big eight", Tokyo, 2000). Masatsuka of the agreement made at the meeting of the Global compliance program "Education for all" (2014) significantly influenced the justification of the goals in education proposed by the Working group of the open-ended goals of sustainable development ${ }^{1}$.

The main consumer in the field of adult education becomes an individual with its specific educational needs, then social groups, social institutions, including the state, and society as a whole. This determines the requirement of breadth and flexibility of the system, its adaptation in all respects (place, time and terms of training, variety of programs, certification levels), as well as the use of special technologies of adult education as consumers of educational services.

Often adult education is seen as narrowed as education to ensure pure economic growth and increase the population's chance of employment. However, the mission of education in general, adult education in particular,

\footnotetext{
1 Лук'янова Л. Законодавче забезпечення освіти дорослих: зарубіжний досвід. - Вид-во: ТОВ «ДКС-Центр»- К., 2007. - С. 5.
} 
is much broader and is to attract citizens to a full-fledged multi-faceted social life and not only in the labor market. After all, the need to learn throughout life reflects much more than just an economic need, because education is increasingly playing a key role in restoring stability, dynamic development of society, and its civil, professional, domestic spheres. Adult education in all its dimensions - formal, informal, informal - is aimed at self-development of the individual and, accordingly, should be supported at the state level. This approach, together with the guarantee of the individual's right to education at any age, is the basic norm of legislation in progressive European States. We hope that in a rapidly developing Ukrainian society, the European principles and values regarding the adult education system will become a Ukrainian reality.

Thus, the Concept of development of adult education in Ukraine (2011) emphasizes the need to recognize adult education at the state level as an integral part of the national education system and the development of new approaches to its legal regulation, especially the need to prepare a draft Law "On adult education» ${ }^{2}$.

\section{The historical aspect of the development of adult education}

Historical intelligence suggests that the first officially recorded documents that normalize adult access to education are:

- creation of the first adult school (Nottingham, UK, 1798);

- budget of a special article on subsidies "people's peasant schools", which were the prototype of the people's high schools in Denmark (Denmark, 1852);

- adoption of the law on public education, aimed at supporting the creation of evening and Sunday classes for adults who have not received education or seek to improve their knowledge (Spain, 1857);

- recognition of adult education and the responsibilities of the state to support it (Constitution of the Weimar Republic, 1919).

It is worth mentioning that one of the first books on adult education "The History and development of adult schools" was published in 1816, the author of which was Dr. T. Pole ${ }^{3}$.

Theoretical analysis of literary sources proves that in the west, adult education in the early twenty-first century exists in two major forms: European and American. The history of adult education in the United

2 Лук'янова Л.Б. Концепція розвитку освіти дорослих в Україні. - Ніжин: ПП Лисенко М.М., 2011. $-24 \mathrm{c}$.

3 Лук'янова Л. Законодавче забезпечення освіти дорослих: зарубіжний досвід. - Вид-во: ТОВ «ДКС-Центр» - К., 2007. - С. 6. 
States has its own traditions. So, in 1964 in the USA there were only 16 educational programs for adults. Although the first Department of adult education was established in 1920 in the UK, but only in the 60s of the last century in the Anglo-Saxon civilization there was a sharp increase in the importance of adult education as a special field of academic research.

In 1986, the first international conference on the history of adult education was held at Oxford University, where scientists from great Britain, other countries of Europe, North America and the East and Japan worked. In 1989, at the University of Syracuse (USA), canadian and American scientists implemented a project aimed at analyzing the relationship between vocational education and adult education.

Historical analysis shows that in 1919 the World Association for adult education in London was founded, which functioned before the Second world war. Since 1949, UNESCO has been constantly updating the problems of development of the international movement in the field of adult education. International symposia on adult education were held in Elsinore (Denmark,1949), Montreal (Canada, 1960), Tokyo (Japan, 1972), Paris (France, 1985) and Hamburg (Germany, 1997).

Among the leading humanistic trends in the development of adult education we define the development of national adult education systems in leading European countries, its reform and modernization in the second half of the twentieth century, the development of methodological foundations of continuing education in the EU at the present stage and in the process of their historical formation. However,according to scientists, different interpretations of the methodology of comparative research in the field of adult education, in particular - categories, laws, functions, philosophy, interdisciplinary approach, methodology of andragogics, scientific knowledge, scientific research, development of adult thinking, need to be coordinated.

\section{General provisions of adult education}

Adult education is a social institution historically formed. It is a complex multifunctional socio-psychological-pedagogical and sociocultural system aimed at meeting the professional,educational and personal needs of a person.

Adult education is based on the theory of adult education-andragogy, scientific and methodological basis of which is the technology of adult education. It is also based on the concept of free, "open-education", the 
psychology of adult education, developed in the context of continuous human education throughout life.

In the scientific turnover generally used theoretical and methodological foundations of adult education are the following positions.

An adult student is a person of capable age, socially mature, in general, a personality is formed, which in different ways combines educational activities with employment in the field of paid work. For her, training is not the main activity, because it occurs simultaneously, in parallel with another activity (professional, etc.), family life ${ }^{4}$.

Adult education is a purposeful process of development and education of the individual through the implementation of educational programs and services, the implementation of educational and information activities within and outside the general secondary, vocational, higher and postgraduate education ${ }^{5}$.

The content of adult education due to the goals and needs of society requirements for the system of knowledge, skills, worldview and social and professional qualities of a specialist, formed in the process of andragogically oriented training with the prospects of development of science, technology, technology and culture. The purpose of the adult education system is the realization of the human right to education during life ${ }^{6}$.

The main objectives of the adult education system are:

- to meet the needs of the individual in intellectual, cultural and spiritual development through continuous education;

- formation of students' citizenship, ability to work and live in the conditions of modern civilization, its democratic development;

- preservation and enhancement of moral, cultural and scientific values of the society; dissemination of knowledge among the population;

- raising its cultural and educational level ${ }^{7}$.

Functions of the adult education system:

- adaptive-adaptation to the new requirements of life in a society that is dynamically changing;

\footnotetext{
${ }^{4}$ Анциферова Л. И. Психологические закономерности развития личности взрослого человека и проблема непрерывного образования [Текст]. Психологический журнал. 1980. Т. 1. № 2. - С. 52-60.

${ }^{5}$ Там само.

${ }^{6}$ Бабич М.С. Безперервна освіта (освіта впродовж життя) - умова підвищення національної конкурентоспроможності. / Вісник Хмельницького національного університету 2015, № 5, Т. 1.: [Електронний ресурс]. - Режим доступу: http://yandex.ua/clck/jsredir.

Лук'янова Л. Концептуальні положення освіти дорослих: [Електронний ресурс]. - Режим доступу: http://yandex.ua/clck.
} 
- compensating-reproduction of educational opportunities that were previously absent or lost;

- developing-enrichment of activity opportunities of the person and his spiritual world;

- analytical-research and analysis of factors affecting the need of citizens for continuing education,

- transformative-changes in the educational and qualification level of a person throughout life, as well as the intellectual and cultural level of society;

- prognostic-scientific prediction of the development of personality and society;

- communicative-transfer of social experience from generation to generation;

incentive-stimulation of educational needs of the person ${ }^{8}$.

Principles on which adult education is based:

- recognition of the right to education at any age as one of the leading fundamental human rights;

- orientation of adult education on universal values and ideals of humanism;

- systematic development;

- the continuity;

- accessibility of education;

- interaction and partnership of state bodies, non-governmental and public organizations;

- taking into account the specific educational needs of different categories of adults;

- state support for adult education ${ }^{9}$.

Adult education is characterized by:

- public nature of management;

- variability of programs and terms of training;

- combination of forms of scientific and applied knowledge;

- the voluntary nature of the training;

- systematization of training;

- purposeful activity of those who study;

- focus on meeting the educational needs of individual social and professional groups;

8 Громкова М. Т. Андрагогика: теория и практика образования взрослых: учеб. пособ.: [Електронний ресурс]. - Режим доступу: http://yandex.ua/clck/jsredir. - Загол. з екрану. - Мова укр.

9 Лук'янова Л. Концептуальні положення освіти дорослих: [Електронний ресурс]. - Режим доступу: http://yandex.ua/clck. 
- creating a comfortable educational environment for adult communication; changes ${ }^{10}$.

- possibility of psychological protection in the conditions of social

Main types of adult education:

- formal education, which ends with the issuance of a recognized diploma or certificate;

- non-formal education is carried out in educational institutions or public organizations (clubs), as well as during individual lessons with a tutor, coach and is usually not accompanied by a document;

- informal education is an individual cognitive activity (life experience) that accompanies everyday life and is not necessarily purposeful $^{11}$.

Forms of adult education:

- full-time (fixed - with a margin of production for a certain period of training in educational or educational-professional program;

- evening (shift) - on-the-job training for the period of education or educational and professional program with attendance during the study in his spare time;

- part-time-without interrupting production for a period of training in educational or educational-professional program attend classes during training, during installation and examination sessions;

- external - a special form of on-the-job training, which provides for the independent study of academic disciplines of educational or vocational education programs, the preparation of the final control tests in an educational institution;

- distance learning - is a special form of on-the-job training that provides for the study of educational disciplines of an educational or vocational education program using computer and telecommunication technologies, the preparation of the final control tests in an educational institution;

- under pedagogical patronage - a form of education of persons with special social needs;

- through self-education - a form of non-formal education through the assimilation of educational programs with minimal organization of the educational process or without the guidance of this process on the part of teachers;

\footnotetext{
10 Психологические проблемы образования взрослых [Електронний ресурс]. - Режим доступу: http://www.voppsy. ru/issues/1989/892/ 892005.htm.

${ }^{11}$ там само.
} 
- combined-form - that integrates all the various forms and their elements ${ }^{12}$.

\section{State of development of the problem of adult education in Ukraine}

According to the statistics of adults enrolled in formal and non-formal education, in the early XXI century in the countries of the European Union exceeded 37\%. For example, in Sweden $73 \%$ of the population are involved in adult education, in Norway and Finland -55\%. Ukraine in terms of the level of participation of the adult population in various educational programs belongs to the fourth, the last group of countries in which the number of adult citizens who study is less than $15 \%$.

Adult education in Ukraine is carried out within the legislative framework defined by the Basic law, the framework Law "On education" and other laws, which to a certain extent relate to education ("On General secondary education", "On out-of-school education", "On vocational education", "On higher education", "On scientific and technical activities"), and normative legal acts regulating the education of the ablebodied (employed and unemployed) population. In these and other legislative acts adopted over the past two decades, the ideas of creating conditions for the development and self-realization of the individual during life are declared and normalized.

Currently, the basis of adult education is post-graduate education, financed from the state budget in the amount of $1.0-1.3 \%$ of the total budget for education. These funds are used to improve the skills and retraining of graduates. At the same time, they are not enough to ensure a minimum, at least once every five years, systematic training of workers in all economic activities. The analysis of the situation showed that there are no systematic proposals for the provision of educational programs for adults, taking into account their personal needs, capacity, age. Grant support from the state and local budgets of those organizations and institutions that provide adult education has not been developed, and the activities of international donors are too complicated. In general, there is a lack of financial support and promotion of adult education in the country, in particular through tax breaks, direct payments for adult education and the like. So, often-densely adult education is a personal

\footnotetext{
12 Психологические проблемы образования взрослых [Електронний ресурс]. - Режим доступу: http://www.voppsy. ru/issues/ 1989/ 892/ 892005.htm.
} 
matter and responsibility, its role is not properly understood at the level of public policy.

Among the omissions and miscalculations in the development of adult education is primarily to determine the following:

- the lack of legislative and regulatory framework that specifies the purpose, objectives, functions of adult education, regulate the activities of the subjects of the educational process, their rights and obligations, the nature of interaction with the state, coordination mechanisms between the subjects of management, as well as the principles and forms of financing, and as a consequence, the uncertainty of the status of adult education in society, which hinders the development of an integrated system of education during life;

- uncertainty of the role and tasks of Central and local Executive authorities and local self-government bodies in ensuring interaction between state institutions, non-governmental organizations and social partners in the field of adult education;

- lack of systematic recognition and certification of formal, nonformal and informal adult education, the key component of which is the system of accreditation and evaluation of previous experience, acquired personal competencies;

- the lack of structure of the Ministry of education and science, youth and sports of Ukraine of units of sufficient capacity, necessary for the development, coordination, quality control of adult education.

At the same time, an empirical study was conducted in four districts of Kyiv (Pechersk, Darnitsky, Desnyansk and Podolsk), which was attended by more than 400 people aged 18 to 70 years, showed that the need for adult education is extremely high. Research of citizens was conducted during 2019 in the pension funds of these areas, social services and on the streets of the city. The survey was conducted with the help of the actually developed questionnaire, which consisted of 12 questions aimed at determining the demand for adult education, its content, orientation, features of its implementation and popularization of information about the possibility of adult education. The results of the study showed that the attitude of citizens to adult education is positive, even interested. Respondents of different ages (from 18 to 70) gladly answered the questions and showed a caring attitude to the development and implementation of adult education in Ukraine.

The overwhelming majority of respondents are women (83\%). By age range the subjects were distributed as follows: 18-35 years (17\%), 
36-60 years (25\%), 60-60+ (58\%). The vast majority of the adult population has higher education - 67\%. Identification of the characteristics of the marital status of respondents showed that only $31 \%$ of the subjects are married, the rest: divorced (19\%), widows/widower (28\%), unmarried (22\%).

Determination of the professional orientation of the studied according to the classification of $\mathrm{O}$. Klimov showed that half of them belong to the profession "man-man" - 52\%; the rest were distributed as follows: "man-technology" - 28\%, "man-artistic image" - 8\%, "mannature" $-6 \%$, "man-sign system" - 6\%.

The data obtained showed that $56 \%$ of the respondents have already taken (or are currently taking) part in non-formal educational programs, $44 \%$ of the respondents are not involved in adult education due to lack of information or time. However, $81 \%$ of citizens expressed an urgent need for new knowledge and $75 \%$ of them have a desire to receive education free of charge.

The main purpose of training is self-improvement (61\%), orientation in the modern world (33\%) or further professional activity (6\%). In response to this question, $71 \%$ of respondents chose two of these items. Regarding the form of training, the vast majority of the study $72 \%$ preferred full-time form of education and only $28 \%$ of respondents distance (using computer and telecommunication technologies).

At the same time, $84 \%$ of respondents are focused on formal education, which provides for the certification of knowledge in the form of a certificate or diploma of the state sample. Convenient time for adults day training (64\%). The results of the study of the areas of adult education that are of interest to citizens turned out to be interesting. It turned out that the following branches of knowledge are leading: the new computer technologies (work on the Internet, including social networks) - 30\% and psychology (personal growth training) - 28\%. The rest of the proposed professional areas have up to $5 \%$ of the respondents is elections - transport industry, hotel or tourism, foreign languages, traditional medicine, law and hand-made. Thus, empirical data allow to orient in features of providing educational services to the adult population.

In a free conversation, it was found that the greatest popularity of adult education in the age group $60+$ is due to many factors, such as retirement, loss of family and friends, illness and as a result - the narrowing of the circle of communication and areas of activity. Therefore, adult education for people of advanced age in addition to the above functions can act as a compensatory mechanism in a situation of lack 
of attention and communication. Thus, adult education can resume its importance in the social environment, provide an opportunity for new useful acquaintances and find yourself in a new professional field.

The results of the research formed the basis for the development of training «Modern methods of adult education» in the framework of professional development of the adult which were held at the Taurida national University named after V.I. Vernadsky. Training and work with adults allowed to find out the psychological portrait of an adult student and psychological features of their training.

So, let's focus on the most significant:

- an adult student has a leading role in the learning process. This means that the listener independently determines the zone of the nearest development;

- an adult student has life experience (social, professional), which can be used as an important source of education;

- the education of an adult student is aimed at solving an important life problem and achieving a specific goal;

- an adult student is counting on the immediate use of the knowledge and skills acquired in training (urgency of training);

- the educational activity of an adult student is largely determined by temporal, professional, social factors that limit or contribute to the learning process;

- the learning process of an adult student should be organized in the form of joint activities of the student and the person who teaches at all stages of planning, implementation, evaluation and, to some extent, correction into account the individual approach;

- training of an adult student is characterized by a conscious assessment of the result as a personal neoplasm, which is achieved through its own activity;

- training of an adult student provides for the acceptance by the student of responsibility for their own actions, the result of which is not known in advance;

- an adult student strives for independence in the learning space.

The methodology of adult education must take into account the following positions:

- identify the request of students and take it into account as much as possible in the work;

- set the rules of work and be sure to follow them;

- promote group cohesion and to maintain the working momentum; 
- the material is submitted clearly and structured with the possibility of teacher's explanations and students' comments;

- use of a combined approach to the forms and methods of training (theoretical material with practical exercises, static with mobile activities, individual with group activities, etc.);

- features of communication in the adult learning space should include techniques of active and passive listening, feedback, application of discussion and willingness to hear criticism;

- features of interaction between the teacher/coach of the adult should be based on a partnership, the teacher should act as a tutor/ facilitator/consultant. Relationships should be based on trust and respect for each other.

Features of assimilation of educational material by adult students is characterized by the following:

- the quality of mastering the material depends on the psychophysiological, individual psychological, age, gender characteristics of students and their professional activities;

- awareness of the material (its understanding, the ability to verbalize and apply in practice) increases depending on the acquisition of the status of necessity, importance, novelty, creativity for a particular listener;

- the interest of students is an indicator of teaching (if necessary, it is necessary to adjust the teaching style, content, sequence of presentation, methods and form of training, etc.);

- assessment in the training of adult students becomes important through the ability to evaluate their work on certain criteria, others and certainly teaching.

Factors affecting the learning process of adult students:

- ease of teaching - the material should be accessible to the understanding of each student;

- versatility - the material should be commented on from different sides, not only by the teacher, but also by students with examples from their professional activities;

- flexibility - taking into account the logical and psychological sequence in the supply of material;

- "tasks to home" - tasks are more performed in the classroom.

The most effective were the following teaching methods:

- analysis of practical situations,

- group discussion,

- entertainment business games, 
- the solution of design problems,

- project development,

- brainstorming,

- training exercises.

Therefore, it can be argued that there is a need to address the current challenges facing adult education, but adult education is a factor that provides a direct process of development of the individual and society as a whole. At the same time, the best way to develop adult education in Ukraine should take into account both the specifics of the Ukrainian mentality and the trends of modern world experience.

\section{Priorities for the development of adult education in Ukraine}

In order to develop and implement the state policy in the field of adult education, it is necessary to legislate the requirements for coordination and interaction of various subjects of activity from the systematic and consistent implementation of this education, the recognition of the human right to lifelong education, access to educational and information resources of all kinds.

First of all, at the state level, it is necessary to recognize the public usefulness of adult education and to consolidate guarantees of its development through the allocation of special budget items, the development of methods of financial support for the most "remote" from the education system of social groups; ensuring the availability of educational services for all adults, regardless of age, level of previous education, place of residence, social status. Special attention should be paid to adult education by the state administration, local self-government bodies and public organizations, in particular in the field of non-formal and supplementary adult education.

In order to increase the interest of organizations in the allocation of funds for training, retraining and advanced training of personnel and counteract the trend of savings on training of employees, it is advisable to develop a legal mechanism to stimulate both employees and employers regarding continuous professional and personal improvement. Systemic cooperation between the Executive authorities, the state employment service, line ministries and agencies and employers should play an important role in the implementation of such a mechanism.

The legal framework should reflect the requirements for teaching staff and educational and material resources of organizations, planning and accounting of educational work, qualification growth and career 
advancement of personnel, as well as financing the cost of professional training of workers in both production and non-production areas. Regulation of the financing of staff development costs should include, inter alia, the procedure for determining the current educational and administrative costs of educational institutions.

The issue of reliable state statistics on adult education at the local, regional and national levels is important.

In our opinion, it is necessary to develop adult education as an integral system that reproduces the guarantees and rights of every citizen of the country for lifelong learning; to orient it to universal values, the ideals of humanism; to harmonize the interests of the individual and society, as well as to make the mentioned education accessible to all segments of the population, to create objective conditions for the maximum development of the individual, the realization of all personal potential opportunities, which will contribute to both successful adaptation to changing socioeconomic conditions and social protection of an adult.

In order to implement the state policy in the field of adult education, it is advisable to ${ }^{13}$ :

1. Adopt the Law of Ukraine "On adult education" and relevant bylaws.

2. To secure guarantees for the development of adult education through the allocation of special budget items, the development of a mechanism of financial support for the most "remote" from the education system of social groups, ensuring the availability of educational services for all adults, regardless of the level and direction of previously acquired education, income and place of residence, age and health status.

3. Consider the possibility of a significant expansion of the postgraduate education sector of the Ministry of education and science, youth and sports of Ukraine, including its powers and functions on the coordination and management of the adult education system.

4. To include in the national classifier of Ukraine: Classifier of professions the profession of an andragogist and implemented in higher educational establishments to train personnel for the needs of the labour market and adult education.

5. To introduce a system of real economic incentives for employers to develop and implement professional training of personnel of enterprises, organizations and institutions.

13 Лук'янова Л.Б. Концепція розвитку освіти дорослих в Україні. - Ніжин: ПП Лисенко М.М., 2011. $-24 \mathrm{c}$. 
6. To implement measures to regulate the education and employment of persons with disabilities, to justify the list of integrated professions for the training of persons with disabilities in a modular system of vocational training institutions for professions that are in demand in the labor market.

7. Develop non-formal education for older persons. To this end, to provide comprehensive support from public administration and local selfgovernment bodies for the establishment and operation of associations and interest groups; to stimulate the activities of non-governmental public, sponsor organizations that have joined or are willing to join the implementation of the project "Universities of the third age".

Thus, taking into account the above, it should be emphasized that only a systematic attention to the problems of adult education, a clear national strategy in this area will be able to turn Ukraine into a modern civilized democratic state, where the interests and needs of each person are the concern of the state and society.

\section{CONCLUSIONS}

In the context of the structural restructuring of the economy and the active transition of the our country to market conditions, taking into account the positive foreign experience, the ability and willingness of the population of our country to adapt to new and unexpected situations is becoming increasingly important, which determines the feasibility of the concept of adult education.

Adult education is the process of personal, social and professional development of a person throughout his life, which is implemented in order to improve the quality of life of both the individual and society as a whole. This comprehensive and unifying idea covers formal, non-formal and informal learning; it is embodied in order to achieve the development of all spheres of human life at different levels.

Adult education should be based on the principles of openness, selfdevelopment on the basis of new principles focused on socio-economic changes in society, the existence of differences between educational and professional activities of adults. Flexible learning paths, recognition, certification and accreditation are important in adult education.

Prospects for the development of adult education in Ukraine:

- adoption of the new law "On education" (definition of adult education as an integral part of the lifelong education system); 
- definition with approaches to management (and financing) of formal and non-formal adult education at the state, regional, city/ district levels;

- development and adoption of the bill "On adult education";

- inclusion of adult education in regional and local development plans;

- formation of public opinion on adult education and education.

\section{SUMMARY}

The article presents modern views on adult education in Ukraine and abroad. The article outlines the actual problems of the adult educational space, the historical aspect of the problem, the essence of adult education, its purpose, objectives, principles, functions, forms and types of adult education. The article presents an empirical study devoted to the study of the demand for adult education in Kiev, its content, features of the implementation and promotion of information about the possibility of adult education. The materials also contain the results of practical experience in the training program "Modern methods of adult education" on the basis of Taurida national University named after V.I. Vernadsky, which are identified during the psychological characteristics of adult education. The article also outlines the shortcomings and prospects of development of adult education in Ukraine. The article may be of interest primarily to scientific and pedagogical workers of higher educational institutions, as well as representatives of the general public who seek to improve the quality of adult education in Ukraine.

\section{REFERENCES}

1. Анцыферова Л.И. Психологические закономерности развития личности взрослого человека и проблема непррывного образования [Текст]. Психологический журнал. 1980. Т. 1. № 2. - С. 52-60.

2. Бабич М.С. Безперервна освіта (освіта впродовж життя) умова підвищення національної конкурентоспроможності. / Вісник Хмельницького національного університету 2015, № 5, Т. 1.: [Електронний ресурс]. - Режим доступу: http://yandex.ua/clck/jsredir.

3. Громкова М. Т. Андрагогика: теория и практика образования взрослых: учеб. пособ. [Текст]. М.: Юнити-Дана, 2005. - 495 с.

4. Давидова В.Д. Методичні рекомендації щодо використання шведського досвіду неформальної освіти дорослих у вітчизняній педагогічній практиці. - Б: ББТ НАУ, 2007. - 43 с. 
5. Державний комітет статистики України. Офіційний сайт державної служби статистики [Електронний ресурс]. - Електронні текстові дані. Режим доступу: http://www.ukrstat.gov.ua.

6. Закон о внесении изменений в Закон об обучении взрослых. [Электронный pecypc]. - Режим доступа: http://estonia.news-city.info/ docs/sistemse/dok_iegzez.htm

7.Закон об обучении взрослых. [Электронный ресурс] (РТ И, 1998, 71, 1200). - [Электронный ресурс]. - Режим доступа: http://rup.ee/rus/pdf/zakoninarusskom/30.pdf.

8. Закон України «Про освіту». [KElektronnij resurs]. - Rezhim dostupu: http://zakon2.rada.gov.ua/laws/show/1060-12.

9. Каган М. С. Системное управление образованием взрослых в условиях модернизации: монография в 3-х т. / Каган М.С., Е.Н. Князева, С.П. Курдюмов; науч. ред. А.И. Жилина. - СПб.: ГНУ ИОВ РАО, 2007. - Т. 2. - 188 c.

10. Колесникова И.А. Основы андрагогики: учеб. пособ. [Текст] / И. А. Колесникова, А. Е. Марон, Е. П. Токоногая. - М.: академия, - 2003. - 240 с.

11. Конституція України. - [Електронний ресурс]. - Режим доступу: http://zakon2.rada.gov.ua/laws/show.

12. Концепція освіти дорослих в Україні / Укл.: Лукянова Л.Б. Ніжин: ПП Лисенко М.М., 2011 - 24 с.

13. Кулюткин Ю.Н. Психология обучения взрослых [Текст]/ Ю. Н. Кулюткин. - М., - 1985. - 128 с.

14. Лук'янова Л. Законодавче забезпечення освіти дорослих: зарубіжний досвід. - Вид-во: ТОВ «ДКС-Центр»- К., 2007. - С. 4.

15. Лук'янова Л. Концептуальні положення освіти дорослих: [Електронний ресурс]. - Режим доступу: http://yandex.ua/clck.

16. Модельная программа подготовки андрагогов: учеб.-метод. пособие / Н.Н. Кошель [и др.]; под. ред. Н.Н. Кошель. - Минск: АПО, 2011. - $314 \mathrm{c}$.

17. Мониторинг непрерывного образования: инструмент управления и социологические аспекты. Сер. «Мониторинг. Образование. Кадры» / Науч. рук. А.Е. Карпухина. М.: МАКС Пресс, 2006. - $340 \mathrm{c}$.

18. Муниципальное образование для взрослых. - [Электронный pecypc]. - Rezhim dostupu: http://www.government.se/sb/d/6997/a/ 67936.

19. Образование взрослых - ключ к XXI веку. - Екатеринбург: УГПУ, 2001. - $173 \mathrm{c.}$ 
20. Образование взрослых на рубеже веков: вопросы методологии, теории и практики: в 4 т. - Спб.: ИОВ РАО. - Том 1: Социально-экономические и правовые предпосылки развития образования взрослых. Книга 2: Политика в области образования взрослых / Под ред. В.И. Подобедова, Н.П. Литвиновой. - 324 с.

21. Образование: Сокрытое сокровище: Доклад Международной комиссии по образованию для XXI века, представленный ЮНЕСКО. - Издательство ЮНЕСКО. - 1996 - [Электронный pecypc]. - Режим доступа: http://www.ifap.ru/library/book201.pdf.

22. Образование взрослых как социальный институт / под ред. Е.П. Тонконогой, В.И. Подобеда. - СПб. : ИОВ РАО, 1999. - 216 с.

23. Обучение взрослых: учиться никогда не поздно // Коммюнике Комиссии Европейских Обществ, Брюссель, 23 октября 2006 года. КОМ (2006) 614 окончательный [Электронный ресурс]. Режим доступа: http://www.google.com.ua/url?sa=t\&source=web\& $\mathrm{cd}=1 \&$ ved $=0$ CB.

24. Освіта дорослих в Україні через призму європейського досвіду: збірка матеріалів. - DVV international. - Київ, 2011. - 117 с.

25. Психологические проблемы образования взрослых [Электронный peсурс]. - Режим доступа: <http://www.voppsy.ru/ issues/ 1989/ 892/ 892005.htm.

26. Развитие психологических функций взрослых людей [Текст] / под ред. Б. Г. Ананьева, Е. И. Степановой. - М., - 1977. - 200 с.

27. Сікорський П.І. Теорія і методика диференційованого навчання: монографія [Текси]. - Л.: Сполом, - 2000. - 421 с.

28. Система неперервної освіти: здобутки, пошуки, проблеми. Чернівці, 1996. - 234 с.

29. Гадзирадієва С.К. Навчання дорослих як наукова проблема [Електронний ресурс]. - Режим доступу: 23.02.2008: http://www.lips.zp. ua/index.php?option=com_content\&view=article\&id=264:120032\& c atid $=47$ :states \&Itemid $=79$

\section{Information about the author: Maslianikova I. V.}

Candidate of Psychological Sciences, Associate Professor, Associate Professor at the Department of Psychology and Pedagogy of the Educational and Scientific Institute of Humanities of the V. I. Vernadsky Taurida National University 